\title{
Л.Л. АРЗУМАНОВА*
}

\section{О МЕСТЕ ЭМИССИОННОГО ПРАВА В СИСТЕМЕ ФИНАНСОВОГО ПРАВА РОССИЙСКОЙ ФЕДЕРАЦИИ}

Ключевые слова: эмиссионное право, финансовое право, система права, подотрасль права

Финансовое право, являясь одной из отраслей российского права, обладает своим предметом, методом правового регулирования и системой. Так, под системой финансового права понимается «объективно обусловленное системой общественных финансовых отношений внутреннее его строение, объединение и расположение финансово-правовых норм в определенной последовательности» ${ }^{1}$. Таким образом, система финансового права предполагает наличие определенных элементов, совокупность которых и составляет ее внутреннее строение. Элементы этой системы находятся в постоянном взаимодействии друг с другом, обеспечивая функционирование всей системы в целом. Элементы системы финансового права образуются финансово-правовыми нормами, сгруппированными в обособ-

(С) Арзуманова Л.Л., 2012

* Кандидат юридических наук, старший преподаватель кафедры финансового права Московской государственной юридической академии имени О.Е. Кутафина. [llarzumanova@yandex.ru]

Статья подготовлена в ходе выполнения поисковой научноисследовательской работы в рамках реализации ФЦП «Научные и научнопедагогические кадры инновационной России» на 2009-2013 гг.

${ }^{1}$ Финансовое право: учебник / отв. ред. Н.И. Химичева. 4-е изд., перераб. и доп. М., 2009. С. 59. 
ленные институты и подотрасли на основе единства предмета их правового регулирования.

Одним из элементов системы финансового права является подотрасль, включающая в себя несколько институтов. Выделение подотраслей связано с наличием большого количества норм, регулирующих относительно обособленные и однородные отношения, которые входят в предмет отрасли права. Традиционно в системе финансового права выделяют две подотрасли: бюджетное и налоговое право. Между тем основной тенденцией развития учения о системе финансового права последних лет стало выделение еще целого ряда подотраслей, таких как: подотрасль финансового контроля ${ }^{2}$, учетное право ${ }^{3}$, право денежного обращения ${ }^{4}$, а также ряд других.

Здесь следует отметить высказываение Н.И. Химичевой, согласно которому «по финансовому праву такой последовательной группировки правовых норм по разделам, подотраслям, институтам и по ее официальному оформлению пока еще не существует» ${ }^{5}$, таким образом, констатировав, что вопрос о системе финансового права до сих пор остается актуальным. В рамках же настоящего исследования поставлена задача определить место эмиссионного права в системе отрасли финансового права.

Так, в науке финансового права нормы, которые регулируют вопросы денежного обращения и валютного регулирования, рассматриваются в качестве двух самостоятельных институтов, входящих в Особенную часть отрасли финансового права. Такой позиции, например, придерживается О.Н. Горбунова, выделяющая институт «деньги и денежное обращение», а также институт «валютного регулирования» ${ }^{6}$.

В частности, Е.М. Ашмарина выделяет право денежного обращения и валютное право в качестве подотраслей финансового права ${ }^{7}$.

${ }^{2}$ См.: Грачёва Е.Ю. Проблемы правового регулирования государственного финансового контроля: автореф. дис. ... д-ра юрид. наук. М., 2000. С. 10; Грачёва Е.Ю. Финансовый контроль - подотрасль финансового права // Финансовое право. 2002. № 2. С. 57-62.

${ }^{3}$ См.: Аимарина Е.М. Финансово-правовые аспекты учетных систем в Российской Федерации: автореф. дис. ... д-ра юрид. наук. М., 2005. С. 15; Ашмарина E.M. Структура финансового права РФ на современном этапе // Государство и право. 2004. № 9. С. 96; Аимарина Е.M. Место норм, регулирующих учетные процессы в системе финансового права Российской Федерации. М., 2004. С. 151170.

${ }^{4}$ См.: Ситник А.А. Финансово-правовое регулирование денежного обращения в Российской Федерации: дис. ... канд. юрид. наук. М., 2010.

${ }^{5}$ Финансовое право: учебник / отв. ред. Н.И. Химичева. С. 61.

${ }^{6}$ См.: Финансовое право: учебник / отв. ред. О.Н. Горбунова. 3-е изд., перераб. и доп. М., 2006. С. 34.

${ }^{7}$ См.: Ашмарина Е.М. Структура финансового права РФ на современном этапе // Государство и право. 2004. № 9. С. 86-89. 
По мнению же А.И. Худякова, институт «денежное обращение и расчеты» не относится к предмету финансового права, а является гражданско-правовым, поскольку регулирует денежную ветвь товарно-денежных отношений. Финансово-правовым является институт «правовые основы денежной системы», который входит в состав Общей части, так как «этот институт имеет выход на все денежные отношения, в то время как финансовые отношения являются лишь частью их» ${ }^{8}$. В этот же институт им включается институт «валютного регулирования».

Иначе к рассмотрению данной проблемы подходит К.С. Бельский, который пишет, что финансово-правовые нормы, регулирующие денежное обращение, образуют правовой институт эмиссионного права. Эмиссионное право представляет собой «совокупность правовых норм, регулирующих общественные отношения в области эмиссионной деятельности Центрального банка РФ и кредитных учреждений (банков), направленной на организацию в стране наличного и безналичного денежного обращения». По мнению К.С. Бельского, «эмиссионное право образует правовой институт, который входит в состав финансового права... через банковское (публичное) право»9. Так, С.В. Запольский отмечает стремительное формирование эмиссионного права в качестве отдельной подотрасли, в которую также включается валютный контроль ${ }^{10}$. Д.В. Винницкий указывает на то, что эмиссионное право (правовые основы денежного обращения), наравне с бюджетным и налоговым правом, выступает основным компонентом финансового права. По его мнению, систему эмиссионного права образуют: институт, закрепляющий основы денежной системы; институт, регулирующий организацию наличного денежного обращения; институт, регулирующий организацию безналичного денежного обращения; институт, закрепляющий основные инструменты и методы денежно-кредитной политики. Кроме того, Д.В. Винницкий не выделяет валютное право в качестве самостоятельного института финансового права, поскольку, по его мнению, «валютные отношения не направлены на формирование, распределение и использование публичных фондов денежных средств» ${ }^{11}-$ отношения, материальным объектом которых является валюта, возникают в рамках

8 Худяков А.И. Финансовое право Республики Казахстан. Общая часть. Алматы, 2001. С. 99.

См. также: Худяков А.И. Дискуссионные вопросы предмета финансового права // Финансовое право. 2009. № 3. С. 4.

${ }^{9}$ Бельский К.С. Эмиссионное право как институт финансового права // Государство и право. 2006. № 5. С. 55.

${ }^{10}$ См.: Запольский С.В. О модернизации доктрины российского финансового права // Финансовое право. 2008. № 4. С. 17; Запольский С.В. Дискуссионные вопросы теории финансового права. М., 2008. С. 85-87.

11 Винницкий Д.В. Основные проблемы теории российского налогового права: дис. ... д-ра юрид. наук. Екатеринбург, 2003. С. 336. 
налогового, бюджетного и эмиссионного права, а также в рамках иных институтов финансового права.

Озвученные выше позиции свидетельствуют о том, что вопрос о месте эмиссионного права в системе отрасли финансового права в науке не получил однозначного решения.

Подводя итог вышесказанному, можно обозначить следующее:

1. Регулирование обращения национальной и иностранной валюты должно осуществляться в рамках одного элемента отрасли финансового права.

2. В данный правовой элемент должны входить нормы, регулирующие расчетные отношения, поскольку они опосредуют движение денежных средств. Так, Н.И. Химичева отмечает, что «в процессе функционирования финансовой системы производятся денежные платежи и расчеты, т.е. используется денежная система. Эти платежи и расчеты производятся как в безналичной форме, так и с использованием наличных денежных знаков» ${ }^{12}$. Однако здесь следует говорить лишь о тех расчетных отношениях, которые регулируются императивными нормами, поскольку расчетные отношения, основанные на принципе диспозитивности, входят в предмет уже гражданского права.

3. Финансово-правовые нормы, регулирующие отношения в сфере эмиссионного права, следует относить к Особенной части финансового права. Так, в работе Е.Р. Денисова было отмечено, что «функционирование финансовой системы в материальном смысле обеспечивается движением наличных денег и безналичными расчетами» ${ }^{13}$. Основываясь на этом постулате, Е.Р. Денисов указывает, что денежное обращение необходимо рассматривать в качестве института Общей части финансового права.

Безусловно, что денежное обращение составляет основу для развития денежной системы, но трудно согласиться с тем, что эмиссионное право следует относить к Общей части.

Традиционно в науке финансового права к Общей части относят положения, закрепляющие понятийный аппарат, принципы, правовые формы и методы осуществления финансовой деятельности, статус субъектов финансового права, виды, формы и методы финансового контроля, а также ряд других положений. Так, в теории права общие нормы относятся к специализированным нормам и не являются самостоятельной нормативной основой для возникновения правоотношений ${ }^{14}$. Однако финансовоправовые нормы, регулирующие отношения в сфере эмиссионного права, могут стать основанием для возникновения правоотношений. В связи с

12 Финансовое право: учебник / отв. ред. Н.И. Химичева. 4-е изд., перераб. и доп. С. 35 .

${ }^{13}$ Финансовое право: учебник / отв. ред. Е.М. Ашмарина, С.О. Шохин. М., 2009. C. 581.

${ }^{14}$ См.: Алексеев С.С. Общая теория права. В 2 т. Т. 2. М., 1982. С. 70-71. 
этим следует вспомнить слова Р.О. Халфиной, которая отмечала, что «построение Общей части имело своей целью выявление внутреннего единства... финансового права как отрасли ... права и установление его основных принципов. Специальная часть должна устанавливать группы правоотношений и институты... финансового права» ${ }^{15}$.

4. Анализ различных точек зрения относительно места эмиссионного права или, как его называют, права денежного обращения в системе финансового права, позволяет говорить о необходимости выделения особой подотрасли финансового права - эмиссионного права.

Основными критериями в решении вопроса о выделении норм права в отдельую подотрасль являются: а) предмет правового регулирования; б) метод правового регулирования; в) система права; г) наличие сформировавшейся обособленной нормативной базы ${ }^{16}$.

Остановимся на базовых, а именно на предмете и методе правового регулирования.

Так, предметом финансового права являются общественные отношения, возникающие в процессе финансовой деятельности государства и муниципальных образований. Из чего следует, что предмет эмиссионного права можно определить как общественные отношения, возникающие в процессе финансовой деятельности органов государственной власти и местного самоуправления, направленной на организацию денежного обращения (т.е. в наличной и безналичной форме, выраженной в национальной или иностранной валюте).

Метод же эмиссионного права определяется его предметом. Так, методом признается совокупность приемов и способов, с помощью которых осуществляется правовое регулирование общественных отношений. Поскольку эмиссионное право рассматривается как подотрасль финансового права, то его метод должен быть схож с методом финансового права. Следовательно, метод эмиссионного права - метод властных предписаний.

Подводя итог вышесказанному, можно сделать вывод, что эмиссионное право, являясь подотраслью финансового права, представляет собой совокупность правовых норм, регулирующих общественные отношения, возникающие в процессе финансовой деятельности органов государственной власти и местного самоуправления, направленной на организацию денежного обращения (т.е. в наличной и безналичной форме, выраженной в национальной или иностранной валюте).

\section{Материал поступил в редакцию 01.12.11.}

${ }^{15}$ Халфина Р.О. К вопросу о предмете и системе советского финансового права // Вопросы советского административного и финансового права/ отв. ред. В.М. Коток. М., 1952. С. 210.

16 См.: Бельский К.С. Полицейское право: лекционный курс / под ред. А.В. Куракина. М., 2004. С. 47. 